\title{
Skin Bacteria and Skin Disinfection Reconsidered
}

\author{
SYDNEY SELWYN, HAROLD ELLIS
}

British Medical fournal, 1972, 1, 136-140

\section{Summary}

Large discrepancies in the available data on skin microbiology stimulated investigations of the number, interactions, and location of commensals and the true efficiency of disinfection by using skin biopsy, culture of frozen sections, and other methods.

Most current procedures were less than $0.5 \%$ as sensitive as the biopsy method described. This gave mean bacterial counts ranging from $4,400 / \mathrm{cm}^{2}$ on the breast to $400,000 / \mathrm{cm}^{2}$ in the axillae. An iodine preparation removed $95 \%$ of accessible organisms, but about $20 \%$ of bacteria were protected by follicles, crevices, and lipids. Commensals in over $20 \%$ of people produced antibiotics against a wide range of pathogens. Conversely, "satellitism" was demonstrable in $12 \%$ of people.

\section{Introduction}

Though the human skin is uniquely accessible to investigation there is, paradoxically, less well established information about its bacteriology than is the case with the urogenital, respiratory, or alimentary tract. A general review of the subject by Russell (1962) encompassed an apparently sound body of facts. However, the work of the succeeding decade has changed complacency into uncertainty, and the modern literature on skin microbiology contains alarming contradictions about the size and exact nature of the normal microbial population and its precise location in the skin (Marples, 1969). Moreover, in studies on skin disinfection a notable fallacy has been to regard those bacteria that are accessible to standard sampling methods as the total resident flora.

We have attempted in the work described here (a) to determine which of the many existing methods of sampling skin for micro-organisms yields the most complete information; (b) to develop new methods for precisely locating skin microorganisms in their natural habitat and for studying in a realistic way the efficiency of skin disinfection; $(c)$ to assess the possible importance of normal commensals in the skin's ecology; and (d) to provide a rational basis for routine procedures that are aimed at preventing infections of surgical wounds.

\section{Materials and Methods}

The medium used throughout was conventional nutrient agar with the addition of $0.5 \%$ Tween 80 and $0.5 \%$ glucose at $\mathrm{pH}$ 6.5. Duplicate aerobic and anaerobic cultures were incubated at $33^{\circ} \mathrm{C}$ for 72 hours.

\section{SKIN SAMPLING METHODS}

Paired specimens of unprepared and disinfected skin were excised in approximately $1-\mathrm{cm}$ squares both at the start of routine surgical procedures and also from a series of cadavers

Westminster Medical School and Hospital, London SW1P 2AR SYDNEY SELWYN, B.SC., M.D., Senior Lecturer in Bacteriology HAROLD ELLIS, M.CH., F.R.C.s., Professor of Surgery (mainly cases of sudden death stored under refrigeration for less than 24 hours). The full-thickness specimens were placed in sterile Petri dishes and measured. They were then, without delay, transferred to sterile bottles for a two-minute mechanical shake in $10 \mathrm{ml}$ of a sterile solution of $0.1 \%$ Triton X-100 in $0.075 \mathrm{M}$ phosphate buffer at $\mathrm{pH} 7.9$-a solution which gives optimal dispersal of bacteria from skin and yet is free from antibacterial action (Williamson, 1965). Poured plates were made with the resultant bacterial suspensions by mixing $0.02-, 0 \cdot 2-$, and $1-\mathrm{ml}$ volumes, in triplicate, with molten agar in standard Petri dishes. Specimens after disinfection were examined by filtering $1-$ and $8-\mathrm{ml}$ volumes (with neutralizers) through Millipore filter discs $(0.45-\mu \mathrm{m}$ pore size), which were then cultured on the agar medium.

Microscopical studies were performed on coverslip preparations of $10-\mu \mathrm{m}$-thick frozen sections made from excised skin that had been snap-frozen over carbon dioxide. Some sections were examined direct, but most were first incubated for six hours or more on agar before Gram-staining.

Other methods used were: a cylinder-scrub procedure, standardized swabbing, self-adhesive tape stripping, direct contact plates, and velvet pad transfer. In the first method a hollow polypropylene cylinder $3 \mathrm{~cm}$ long and $3.8 \mathrm{~cm}^{2}$ internal area was pressed vertically on the skin surface; $2 \mathrm{ml}$ of the Triton $\mathrm{X}-100$ solution was added, and through this liquid the skin was vigorously rubbed with a blunt-ended Teflon rod for 30 seconds. Standardized swabbing involved firmly rubbing a skin area 5 by $1 \mathrm{~cm}$ for 30 seconds with a throat swab moistened with Triton X-100 solution. The swab tip was broken into a bijou bottle containing $2.5 \mathrm{ml}$ of Triton X-100 solution. After agitation this solution and liquid from the cylinders were cultured as for skin washings.

The remaining three methods provided "maps" of skin bacteria. Sellotape in strips $2.5 \mathrm{~cm}$ wide was tested to exclude antibacterial activity, and the adhesive surfaces of 5-cm lengths were firmly applied to the skin, and were then pressed on agar. Duplicate strips were taken from adjacent areas, one being placed only in transient contact with the medium and one being left in place during incubation. The latter always gave counts that were 5 to 12 times higher, but the colonies were not accessible for detailed study. Contact plates were made on special Sterilin Petri dishes (5.5 cm diameter, type HP4) which present a raised agar surface to the skin. Velvet pads were made by bonding non-inhibitory samples of velvet to ebonite discs ( $8 \mathrm{~cm}$ diameter), and a handle was glued to the back. After autoclaving in paper bags the velvet surface was pressed firmly on the skin and then briefly on agar.

\section{DISINFECTANTS AND NEUTRALIZERS}

The preparations used were: $1.5 \%$ iodine in $70^{\circ} \%$ ethanol, $0.5 \%$ chlorhexidine in $70 \%$ ethanol, $0.5 \%$ aqueous chlorhexidine, $10^{\circ}$ o aqueous benzalkonium chloride, and $0.1 \%$ thiomersal. Neutralizers for diluents and media were as recommended by Rubbo and Gardner (1965). All disinfectants were briskly rubbed on the skin for 15 seconds and allowed to act for 30 seconds before sampling.

\section{TESTS FOR BACTERIAL INTERACTIONS}

Agar in $25-\mathrm{cm}$-square assay plates was flood-seeded with $10 \mathrm{ml}$ of broth containing approximately $10^{5}$ colony-forming units 
TABLE I-Total Bacterial Counts from Skin by Excision or Scrub

\begin{tabular}{|c|c|c|c|c|c|c|c|c|c|c|}
\hline \multirow[b]{3}{*}{$\begin{array}{l}\text { Abdomen } \\
\text { Axilla } \ldots . \\
\text { Interscapular } \\
\text { Scalp .. } \\
\text { Forearm } \\
\text { Thigh . } \\
\text { Breast . }\end{array}$} & \multirow[b]{3}{*}{ 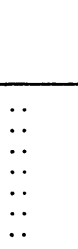 } & \multirow[b]{3}{*}{$\begin{array}{l}\because \\
\because \\
\because \\
\because \\
\because\end{array}$} & \multirow[b]{3}{*}{ 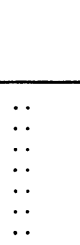 } & \multirow[b]{3}{*}{$\begin{array}{l}\because \\
\because \\
\because \\
\because \\
\because \\
.\end{array}$} & \multicolumn{6}{|c|}{ Mean Counts* per $\mathrm{cm}^{2}$ (Anaerobic ${ }^{11}$ in Parentheses) } \\
\hline & & & & & \multicolumn{2}{|c|}{ Excised Specimens from 20 Cadavers } & \multicolumn{2}{|c|}{ "Scrub" Specimens from 42 Volunteers } & \multicolumn{2}{|c|}{ Surgical Excision } \\
\hline & & & & & $\begin{array}{r}71,300 \\
920,200 \\
46,100 \\
1,356,700 \\
11,200 \\
37,600\end{array}$ & $\begin{array}{r}(50,600) \\
(805,700) \\
(62,300) \\
(1,741,900) \\
(9,600) \\
(36,500)\end{array}$ & $\begin{array}{r}5,100 \\
80,300 \\
7,400 \\
2,300\end{array}$ & $\begin{array}{r}(4,800) \\
(65,600) \\
(9,200) \\
(2,200)\end{array}$ & $\begin{array}{r}30,400 \\
395,000\end{array}$ & $\begin{array}{c}(28,100) \dagger \\
(346,400) \ddagger\end{array}$ \\
\hline
\end{tabular}

- To nearest 100 organisms. † From 35 patients. ‡ From 5 patients. $\$$ From 7 patients. 11 Mostly aerobes capable of anaerobiosis

of a type 7 Micrococcus (Baird-Parker, 1965). A group D diphtheroid (Evans, 1968) was used in parallel. The organisms had been selected in pilot studies as being very sensitive to inhibitory substances produced by several staphylococci. The agar surface, when dry, was inoculated in stabs with predominant organisms from skin cultures. After aerobic incubation any inhibition zones were measured. Similar tests were done with very small colony forms from skin cultures being used as background. Any "satellitism" around the stabs was noted after incubation.

\section{Results}

\section{BACTERIAL COUNTS}

Counts of aerobes and anaerobes (including facultative anaerobes) from various sites measured in two ways are given in Table I.

On a further 12 volunteers and 10 cadavers abdominal skin was simultaneously sampled by all the available methods (including excision, on cadavers). Compared with the excision procedure, the efficiencies of the other methods for sampling accessible organisms were: scrub $4-15 \%$, swab 3-20\%, tape $<0.5 \%$, direct contact $<0.2 \%$, pad $<0.1 \%$. The predominant flora consisted of non-pathogenic staphylococcus/micrococcus strains and diphtheroid bacilli, as expected (Somerville, 1969).

\section{EFFICIENCY OF SKIN DISINFECTION}

The action of several popular surgical disinfectants was tested on abdominal skin by means of biopsy, cylinder-scrub, and tape sampling (Table II). A typical pair of biopsy results from iodine-disinfected and control areas was 1,690 and 38,700 bacteria per $\mathrm{cm}^{2}$.

TABLE II-Apparent Activity of Disinfection at Operation Site

\begin{tabular}{|c|c|c|c|c|}
\hline & & \multicolumn{3}{|c|}{$\begin{array}{c}\% \text { Reduction in Accessible Bacteria } \\
\text { Sampled by }\end{array}$} \\
\hline & & Scrub & Biopsy & Tape† \\
\hline $\begin{array}{l}\text { Iodine in } 70 \% \text { ethanol } \\
\text { Chlorhexidine in } 70 \% \text { ethanol } \\
\text { Chlorhexidine (aqueous) ... } \\
\text { Benzalkonium chloride (aqueous) } \\
\text { Thiomersal (aqueous).. }\end{array}$ & $\begin{array}{l}\cdots \\
\cdots \\
\cdots\end{array}$ & $\begin{array}{l}99 \cdot 6 \\
99 \cdot 3 \\
98 \cdot 1 \\
56 \cdot 7 \\
32 \cdot 1\end{array}$ & $\begin{array}{l}95 \cdot 5 \\
87 \cdot 6 \\
85 \cdot 4\end{array}$ & $\begin{array}{l}72 \cdot 4 \\
55 \cdot 1 \\
50 \cdot 3 \\
34 \cdot 2 \\
18 \cdot 6\end{array}$ \\
\hline
\end{tabular}

- Twenty individuals tested in each category (except biopsies after aqueous chlorhexidine-five cases).

+ Fifteen consecutive strips cultured from each test and control area.

The complete inaccessibility to disinfection of up to $20 \%$ or more of skin bacteria was indicated in two ways. Firstly, serial tape strippings yielded, proportionately, 23-35\% more bacterial survivors after efficient disinfection than did the standard biopsy method (Table II). However, colonies from tape samples represent indeterminate clusters of bacteria (1-100 cells or more); and if only one bacterium in a large cluster survives disinfection it will produce a normal colony. Less equivocal results were obtained with biopsy specimens after iodine disinfection. The excised skin (about $1 \mathrm{~cm}^{2}$ ) was shaken for five minutes in $70 \%$ ethanol and rinsed in sterile water. A complete series of frozen sections was then made and cultured on agar. In 15 of these processed specimens between 8 and 29 colonies grew out of the sections, compared with 90-250 from untreated biopsy specimens. Sebum-rich scalp and skin from the forehead of fresh cadavers usually retained at least half of their original colony-forming units after thorough disinfection.

\section{LOCATION OF SKIN COMMENSALS}

The results of tape and frozen-section cultures after disinfection indicate considerable numbers of protected, relatively deep skin organisms. Further indirect evidence was obtained by finding that, within five hours of disinfection, areas of skin regained original bacterial counts when protected from external contamination with sterile plastic squares sealed around the edges with sticky tape.
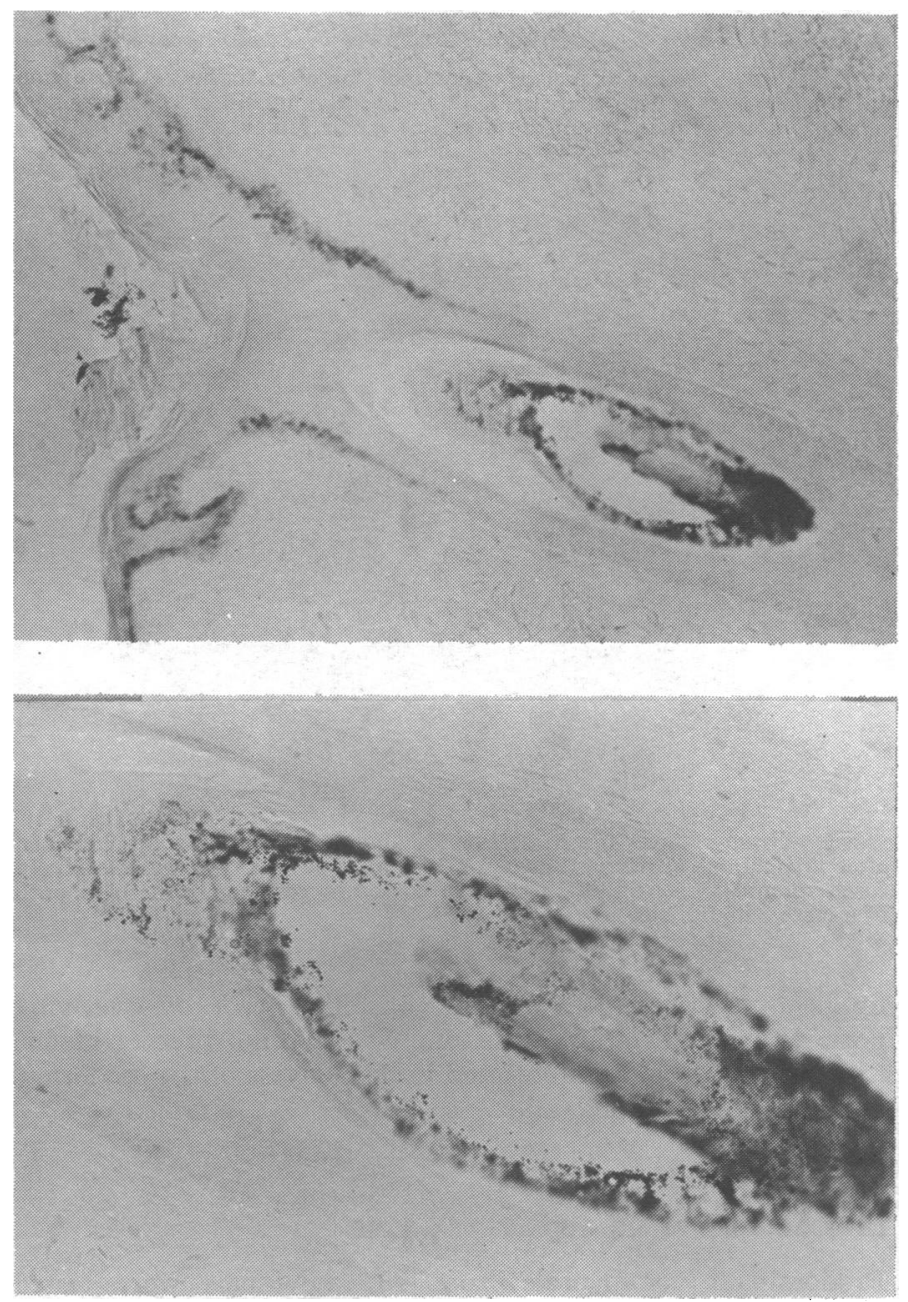

FIG. 1-Large hair follicle in frozen section of abdominal skin biopsy specimen, stained by Gram. Numerous Gram-positive bacilli and cocci lie deep in the follicle. Above, $\times 116$; below, $\times 336$. 
Direct microscopical evidence of a relatively deep flora was obtained by Gram-staining fresh skin sections, as well as by staining frozen sections that had been incubated on nutrient media to obtain microcolonies. Many bacteria (and often yeasts also) were seen surprisingly deep in the larger hair follicles of unincubated skin (Fig. 1). After incubation these bacteria could be seen exuding up the mouths of follicles (Fig. 2). The organisms had not been driven deep by the microtome blade, since the results were similar when skin was cut from the dermal side. More superficially located bacteria formed numerous colonies on incubated sections, even after thorough disinfection of the skin (Fig. 3). These organisms are presumably protected from disinfection by

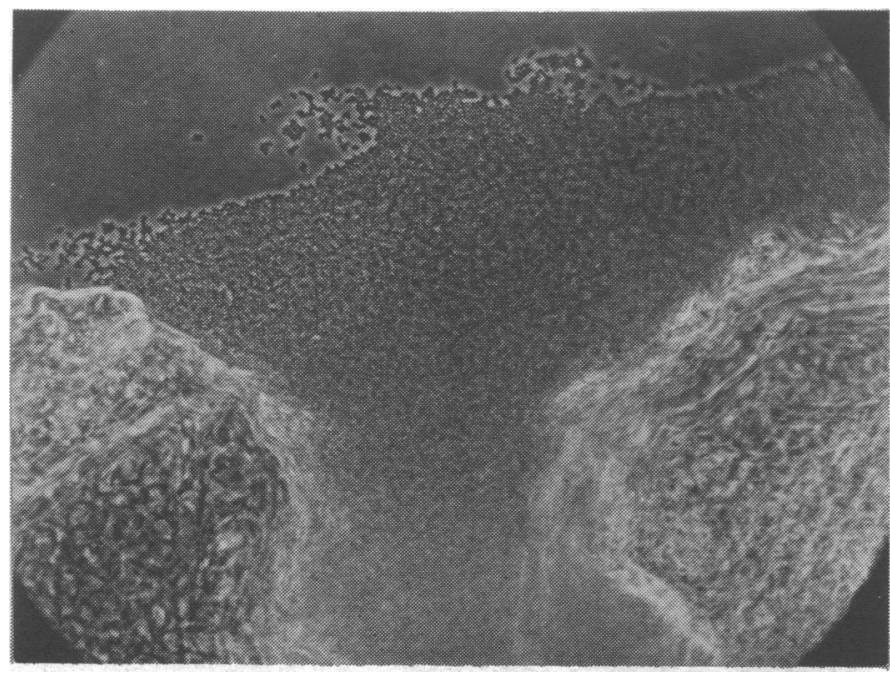

FG. 2-Frozen section of excised abdominal skin after six hours' incubation on nutrient agar (phase contrast $\times 350$ ). Large numbers of cocci arranged in clusters are growing from the depth of a hair follicle and exuding from its mouth.

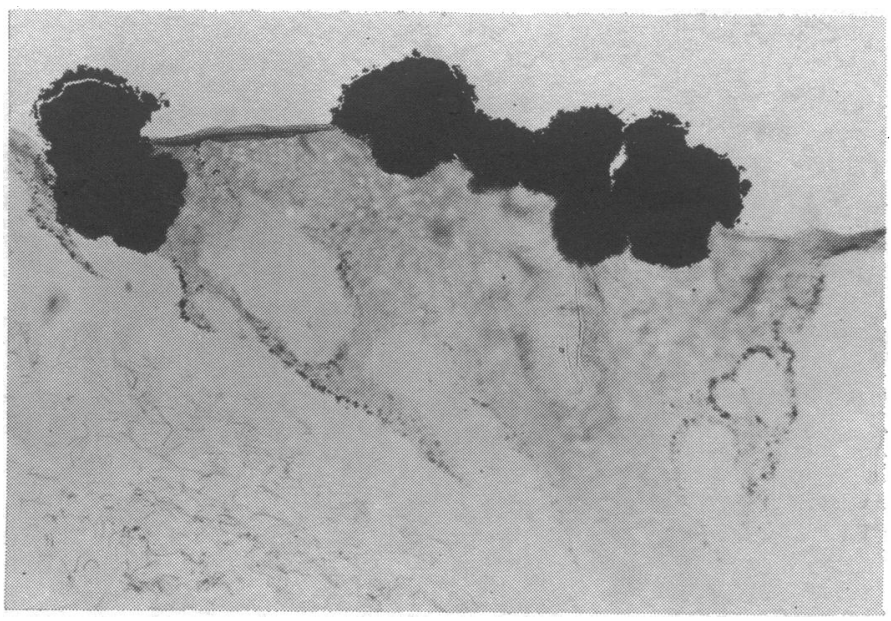

FIG. 3-Gram-stained frozen section of abdominal skin biopsy specimen after incubation on nutrient agar for 16 hours $(x 112)$. Approximately 15 fused microcolonies of Gram-positive cocci are growing from the mouth
of a large hair follicle.

lipids, especially at the mouths of follicles, or by overlying portions of the stratum corneum. We have no direct evidence that bacteria are normally found in deep layers of the epidermis outside pilo-sebaceous units.

\section{INTERACTIONS OF SKIN COMMENSALS}

Predominant commensals from 98 individuals were tested against the two indicator bacteria. Inhibition zones of $2 \mathrm{~mm}$ or more (Fig. 4) were produced by 32 strains from $20(20.4 \%)$

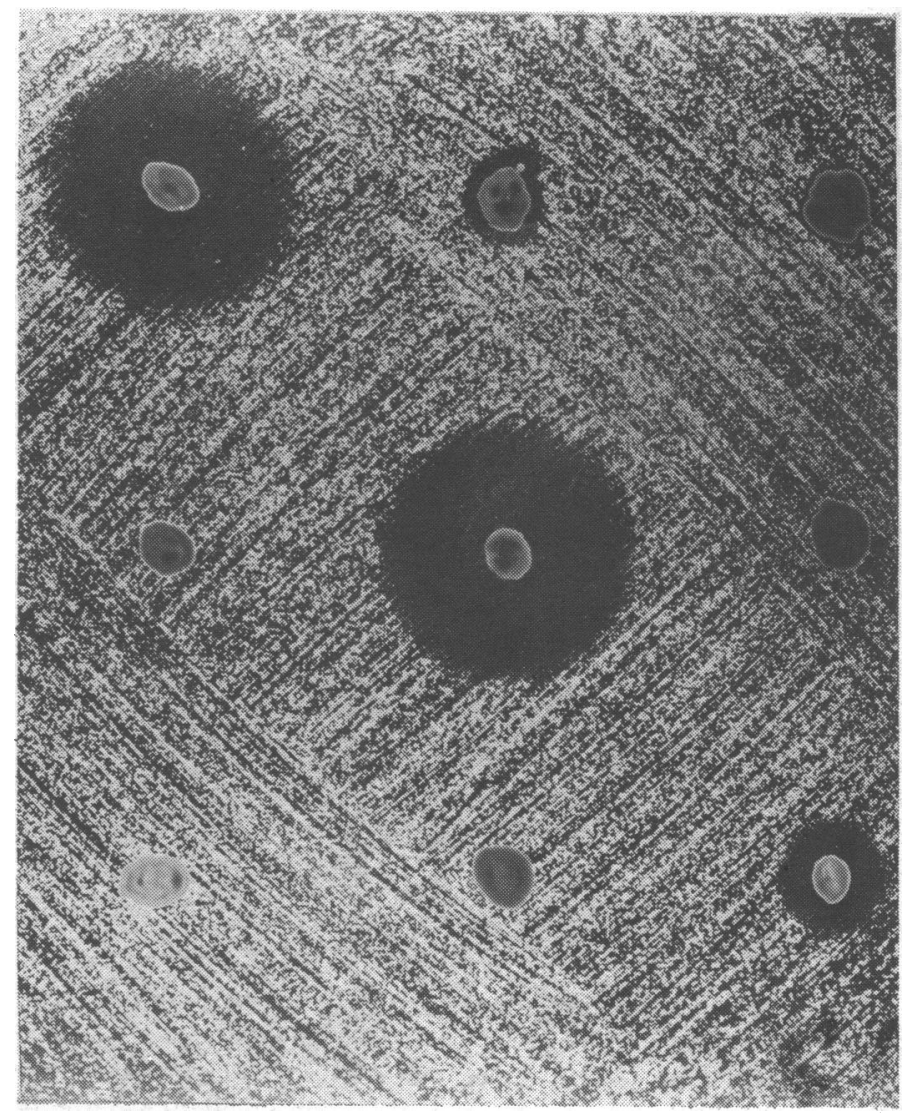

FIG. 4-Part of large agar plate (actual size) with Micrococcus type 7 background inoculated with nine other skin commensals. Various inhibition
zones are present.

of the individuals. All 32 strains were Micrococcaceae, 10 of Micrococcus type 3, 9 of Micrococcus type 5, 7 of Staphylococcus type 2, 4 of Staphylococcus type 3, and 2 of Micrococcus type 7.

Most of these organisms produced inhibition zones against coagulase-positive and coagulase-negative staphylococci and micrococci, Streptococcus pyogenes, Streptococcus viridans, pneumococci, Corynebacterium species (including diphtheriae), Bacillus species, clostridia, and neisseriae. Enterobacteria were not inhibited. On preliminary testing, three inhibitory extracts seem to be polypeptide antibiotics with broader activity than is usual for bacteriocines. Depending on their source, they could be called "staphylococcines" or "micrococcins," but Hsu and Wiseman (1971) named similar substances "epidermidins." Our extracts do not contain lytic substances ("staphylolysins").

Growth enhancement ("satellitism") was produced by most commensal cocci when grown on a background of small-colony forms from skin (Fig. 5). This was found in 12 individuals $(12.3 \%)$ whose satellite organisms were: 2 of Staphylococcus type 3, 4 of Micrococcus type 5, 5 of diphtheroid group A, and 1 of diphtheriod group $\mathbf{D}$.

\section{Discussion}

The major discrepancies in the literature, summarized in Table III, reflect the bewildering range of research methods hitherto used.

\section{BACTERIAL POPULATION}

Though there is general agreement that bacterial counts for skin are subject to large individual variations, nevertheless even the order of reported counts shows an extraordinarily wide range. Thus Dineen (1969), using direct impression 


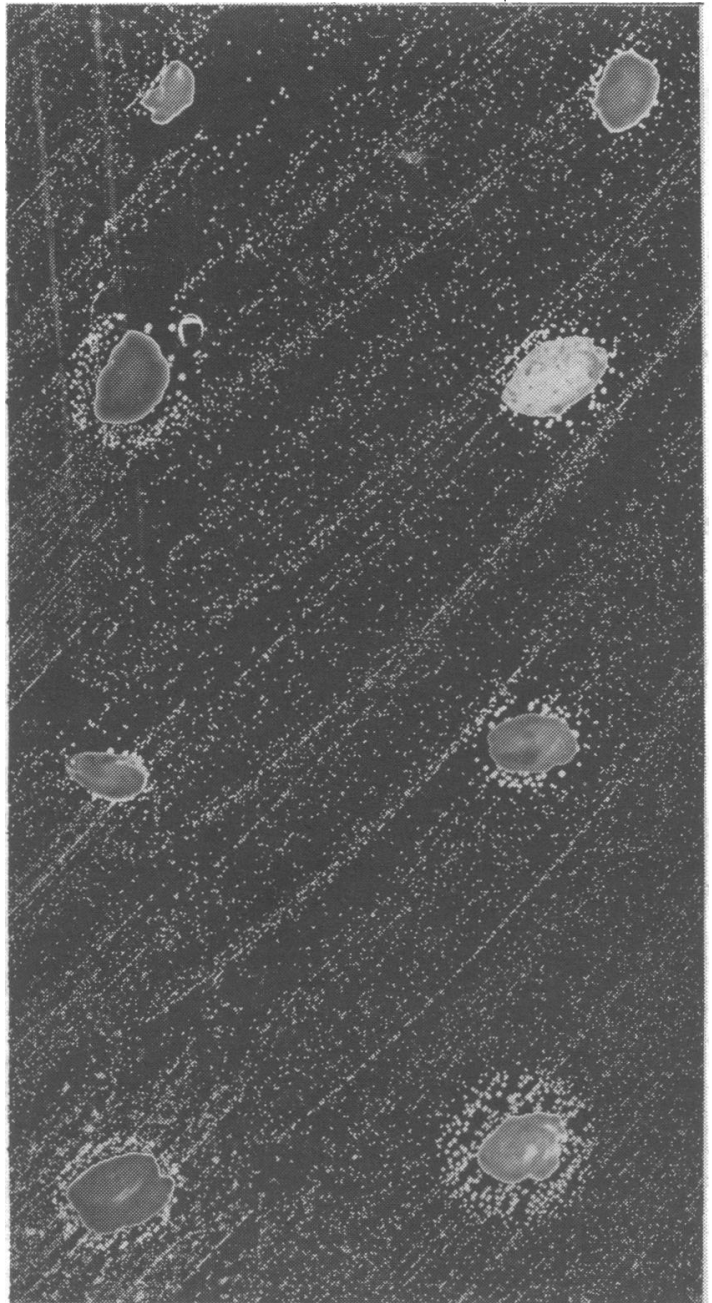

FIG. 5-Part of large agar plate (actual size) with a background growth of a small-colony form of a coagulase-negative staphylococcus. Eight test strains of skin commensals enhance the background growth to varying degrees ("satellitism").

plates, found an average of 70 "cultivable organisms" on five finger-tips-that is, about 14 bacteria per $\mathrm{cm}^{2}$. At the other extreme, Shaw et al. (1970), by swabbing, obtained an average of 100,000 bacteria per $\mathrm{cm}^{2}$ from the back. The high average counts we obtained from the skin biopsies presumably represent as closely as possible the actual numbers of accessible skin bacteria. Our standardized swabbing method is, however, more convenient for routine use, giving realistic results that are about one-sixth to one-tenth the size of biopsy counts. Both methods overcome the problem of bacterial clustering, which in the case of staphylococci can lead to underestimations by a factor of 20 or more. Despite the often-cited work of Evans et al. (1950) and Pachtman et al. (1954), we confirm the view that aerobic organisms greatly outnumber strict anaerobes, except in sebum-rich areas, where Corynebacterium acnes is prevalent.

\section{ANATOMICAI LOCATION OF SKIN ORGANISMS}

Opinion is fairly evenly divided on the exact site of skin colonization. Thus Pecora et al. (1968), using purely qualitative methods, concluded that skin bacteria live entirely at the surface and can be completely removed by simple means. The opposing view was supported scientifically first by Lovell (1945), who briefly incubated pieces of skin and then sectioned them, concluding that a significant proportion of skin bacteria "are situated so deep in hair follicles and sebaceous glands that they cannot be removed without injuring the skin." Montes and Wilborn (1970), using conventional and electron microscopy, seem to have confirmed Lovell's work, but neither they nor Lovell reported any quantitative findings.

Our own results, from serial tape samples after disinfection and from microscopy and culture of frozen sections before and after disinfection, show that up to $20 \%$ or more of the total flora is beyond the reach of routine sampling and disinfection. These bacteria are located not only in pilo-sebaceous units but also in skin crevices and at other sites where lipid and superficial cornified epithelium protect them.

\section{CASE FOR MINIMAL DISINFECTION}

Despite confident statements in the literature-for example Pecora et al. (1968)-that complete sterilization of the skin could easily be achieved by chemical means, we have found that considerable numbers of "resident" skin organisms survive the most thorough treatment. Perhaps this is fortunate. The resident bacteria are rarely pathogenic and, as we have indicated, may be a direct asset to their host. The continual reduction of their numbers by, for example, repeated applications of hexachlorophane may indeed encourage cross-infection with Gram-negative bacteria (Forfar et al., 1968). In addition, the tissue damage caused by standard antiseptics cannot be ignored (Branemark and Ekholm, 1967); and even a substance as apparently harmless as hexachlorophane may be cumulatively toxic (Curley et al., 1971).

Though the nihilistic approach of Dann (1969) seems unwise, relatively brief disinfection of the operation site will usually suffice. We have confirmed by our biopsy and other sensitive techniques that the patient's skin can be readily cleared of virtually all non-sporing contaminants-and accessible commensals-by swabbing with $0.5 \%$ chlorhexidine or $1.5 \%$ iodine in $70 \%$ ethanol which are allowed to act for 30 seconds. Two minutes is only marginally better (Lowbury et al., 1964) and even 15 seconds was found adequate by Gardner (1946). The iodophor, povidone-iodine, in spirit seems to be a satisfactory alternative to iodine in spirit (Lilly and Lowbury, 1971).

\section{NATURAL ANTIMICROBIAL MECHANISMS}

Though the skin is often contaminated with organisms from external and internal sources, it normally supports the growth of only two kinds of bacteria. The most spectacular illustration of its "self-sterilizing" or "autodisinfecting" powers is in the perianal area, which is regularly anointed with enormous numbers of the richly varied intestinal flora following defaecation and anal toilet, especially in the Occidental style; yet usually within an hour or so only the resident staphylococci and diphtheroids have survived (Holt and Leitch, 1970).

A recent review of skin autodisinfection (Lancet, 1968) drew attention to the importance of desiccation at the normal skin surface and also to the part played by fatty acids derived

TABLE III-Principal Contradictions on Skin Microbiology and its Applications

\begin{tabular}{|c|c|c|c|c|}
\hline & & & Published Range of Data or Conclusions & Own Conclusions \\
\hline 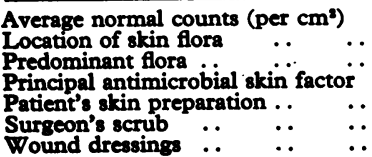 & $\begin{array}{l}\because \\
\because \\
\because \\
\because \\
\cdots\end{array}$ & $\begin{array}{ll}\because & \cdots \\
\because & \cdots \\
\because & \cdots \\
\cdots & \cdots\end{array}$ & $\begin{array}{l}<15 ;>100,000 \\
\text { Surface only; mainly deep } \\
\text { Aerobic; anaerobic } \\
\text { Desiccation; lipids } \\
\text { Several days preop.; }<15 \mathrm{sec} \\
\text { >10 min (vigorous); }<1 \mathrm{~min} \\
\text { Nil; elaborate }\end{array}$ & $\begin{array}{l}\text { c. } 1,000-400,000 \text { depending on site } \\
\text { c. } 20 \% \text { inaccessible to disinfection } \\
\text { Aerobic except in sebum-rich areas } \\
\text { Microbial "interference" also important } \\
1-2 \text { min usually (e.g., iodine in spirit) } \\
\text { Gentle but thorough, }>2 \text { min (e.g., chlorhexidine scrub) }\end{array}$ \\
\hline
\end{tabular}


from skin lipids. However, no mention was made of the probable role of the resident flora itself in deterring visitors or invaders. Even the production of the moderately antimicrobial fatty acids is due to the lipolytic activities of the residentsa fact well known to the makers of deodorants. However, neither desiccation nor lipids can explain the relative rarity of Staph. aureus as a normal skin commensal, since the organism is at least as resistant to these factors as the normal flora. Other mechanisms are undoubtedly involved in the selfregulation of the skin microflora.

Interference among bacteria has already been studied in action following the inoculation of Staph. aureus (strain 502A) on the skin and nostrils of neonates and others. Though this strain does not produce any detectable antibacterial substances (Anthony and Wannamaker, 1967) its use seemed to lead to a pronounced reduction in cross-infection (British Medical fournal, 1968). But the dangers of using even "a relatively avirulent strain" of Staph. aureus have become apparent (Blair and Tull, 1969). Far more attractive is the possibility of using coagulase-negative staphylococci and micrococci, many of which we have shown to be powerful producers of antibiotics. We have recently demonstrated the possible value of these organisms when they occur naturally in surgical and skin patients (to be published). Bacterial "satellitism"- the converse of antagonism-has also been seen during our investigations. The effect may be due to nutritional requirements of fastidious organisms, as with enhancement of Haemophilus influenzae by staphylococci, or to removal of toxic chemicals such as peroxides by growth enhancers, as first reported by Thompson and Shibuya (1946). The possible role of satellitism in skin ecology and infection is as yet totally unexplored, but this should be yet another fascinating area of study in skin microbiology.

We wish to acknowledge the skilled technical assistance of $\mathrm{Mr}$. Derek Manson-Smith during the first part of this work. The illustrations were prepared by the department of medical photography, Westminster Medical School. These investigations were generously supported by the Research Committee, Westminster Hospital, and a grant towards expenses was provided by Leo Laboratories Ltd.

\section{References}

Anthony, B. F., and Wannamaker, L. W. (1967). Fournal of Experimental Medicine, 125, 319.

Baird-Parker, A. C. (1965). Fournal of General Microbiology, 38, 363.

Blair, E. B., and Tull, A. H. (1969). American fournal of Clinical Pathology, 52,42 .

Branemark, P. I., and Ekholm, R. (1967). Fournal of Bone and Foint Surgery, 49A, 48.

Curley, A., Hawk, R. E., Kimbrough, D. R., Nathenson, G., and Finberg, L. (1971). Lancet, 2, 296.

Dann, T. C. (1969). Lancet, 2, 96.

Dineen, P. (1969). Surgery, Gynecology and Obstetrics with International Abstracts of Surgery, 129, 1181 .

Evans, N. M. (1968). British Fournal of Dermatology, 80, 81.

Evans, C. A., Smith, W. M., Johnston, E. A., and Giblett, E. R. (1950). fournal of Investigative Dermatology, 15, 305.

Forfar, J. O., Gould, J. C., and Maccabe, A. F. (1968). Lancet, 2, 177.

Gardner, A. D. (1946), Lancet, 1, 683.

Holt, R., and Leitch, I. (1970). Medical Officer, 123, 345.

Hsu, C. Y., and Wiseman, G. M. (1971). Canadian fournal of Microbiology, $17,1223$.

Lancet, 1968, 2, 96.

Lilly, H. A., and Lowbury, E. J. L. (1971). British Medical fournal, 3, 674.

Lovell, D. L. (1945). Surgery, Gynecology and Obstetrics with International Abstracts of Surgery, 80, 174.

Lowbury, E. J. L., Lilly, H. A., and Bull, J. P. (1964). British Medical fournal, 2, 531.

Marples, M. (1969). British fournal of Dermatology, 81, Suppl. 1, p. 2.

Montes, L. F., and Wilborn, W. H. (1970). Archives of Dermatology, 101,

145.
Pachtman, E. A., Vicker, E. E., and Brunner, M. J. (1954). Fournal of Investigative Dermatology, $22,389$.

Pecora, D. V., Landis, R. E., and Martin, E. (1968). Surgery, 64, 1114.

Rubbo, S. D., and Gardner, J. F. (1965). A Review of Sterilization and Disinfection. London, Lloyd-Luke.

Russell, B. F. (1962). British Medical fournal, 1, 815.

Shaw, C. M., Smith, J. A., McBride, M. E., and Duncan, W. C. (1970). Fournal of Investigative Dermatology, 54, 160.

Somerville, D. A. (1969). British Fournal of Dermatology, 81, Suppl. 1,

p. 14.
Thompson, R., and Shibuya, M. (1946). Fournal of Bacteriology, 51, 671. Williamson, P. (1965). In Skin Bacteria and their Role in Infection, ed.
H. I. Maibach and G. Hildick-Smith, p. 3. New York, McGraw-Hill.

\section{Exchangeable and Total Body Potassium in Patients with Chronic Renal Failure}

Scottish Research Reactor Centre, East Kilbride, Glasgow

KEITH BODDY, M.SC., PH.D., F.INST.P., Senior Lecturer in Health Physics and Nuclear Medicine

PRISCILLA C. KING, M.SC., PH.D., Research Assistant

University Department of Medicine and the Renal Unit, Royal Infirmary, Glasgow

R. M. LINDSAY, M.B., CH.B., M.R.C.P., Senior Registrar in Medicine

J. WINCHESTER, M.B., CH.B., Senior House Officer in Medicine

A. C. KENNEDY, M.D., F.R.C.P., Professor of Medicine
$60 \cdot 7 \pm 3 \cdot 3 \%, 83 \cdot 6 \pm 2 \cdot 7 \%$, and $85 \cdot 9 \pm 2 \cdot 7 \%$ at 24,48 and 64 hours respectively. It seems that the equilibration between radioactive and native potassium is incomplete after 24 hours; and that exchangeable potassium measured at this time is not an accurate index of the status of total body potassium in such patients. Furthermore, the finding that the value at 64 hours is significantly less than found in healthy subjects suggests that the exchangeable potassium is a smaller fraction of the total body potassium in patients with chronic renal failure.

\section{Introduction}

Exchangeable body potassium measured 24 hours after the administration of radioactive potassium has been used as an indicator of potassium status in chronic renal failure (Moore et al., 1954; Seedat, 1969). The findings of these authors were not entirely compatible with those obtained by direct measurements of total body potassium in similar patients by means of whole-body radioactivity monitors (Morgan 